\title{
PENGARUH BIAYA USAHATANI BUAH NAGA TERHADAP KEUNTUNGAN PARA PETANI BUAH NAGA DI DESA TEMUREJO KECAMATAN BANGOREJO KABUPATEN BANYUWANGI
}

\author{
Anggun Norma Isnanda ${ }^{1}$, Hety Mustika Ani ${ }^{1}$, Bambang Suyadi ${ }^{1}$ \\ ${ }^{1}$ Program Studi Pendidikan Ekonomi, Fakultas Keguruan dan Ilmu Pendidikan, Universitas Jember
}

\begin{abstract}
This study aims to examine more deeply about the characteristics of chili farming system in Dusun Tanggulun Lamongan Village Arjasa District Situbondo Regency in the management of land, capital, and labor. Type of research used in this research is descriptive with qualitative approach. Determination of research location determined by Purposive Area method, that is done intentionally by researcher, that is in Dusun Tanggulun Desa Lamongan Arjasa Sub-District Situbondo Regency. The main informants in this study were 5 chili pepper farmers and 9 supporting informants were 5 wives from main informants and 4 farm laborers. Data collection methods used by researchers include interview methods, observation methods, and document methods. Data analysis used in this research consists of several stages, namely data reduction phase, data presentation stage and conclusion drawing stage. The results showed that the chili farmers use the land in the cayenne pepper farm with a semicircular shape that extends or called the bedengan plastic mulch covered. Majority of the main informants use land in the form of beds with mulch plastic covered, the capital is used to buy manure, Urea, ZA, TSP, KCI, Leaf fertilizer, Lime, Plastic mulch, Polibag, Bamboo, Pesticide, and pay land-making farm workers, Pickers of cayenne pepper, as well as using labor from within the family and from outside the family. This study aims to determine the Influence of Dragon Fruit Farming Costs on Profit of the Dragon Fruit Farmers in Temurejo Village, Bangorejo Sub-district, Banyuwangi District. The research approach used in this research is quantitative research. Research subjects are dragon fruit farmers in the Village Temurejo Bangorejo Banyuwangi as many as 50 farmers. Data collection methods used consisted of questionnaire method, observation, interview, and document. The results showed that there is a significant effect of dragon fruit cost variable on the profit of dragon fruit farmers in Temurejo Village, Bangorejo Sub-district, Banyuwangi Regency is $78.6 \%$, while the remaining $21.4 \%$ is influenced by other independent variables which are not examined in this research Namely the use of technology, production quality, and production consumer.
\end{abstract}

Keywords: Cost, Benefit, Dragon Fruit Farming

\section{PENDAHULUAN}

Jawa Timur merupakan daerah penghasil buah-buahan dan sayuran serta tumbuhan pangan lainnya dengan berbagai varietas. Dari kondisi tanah yang sangat subur mudah tumbuh berbagai tanaman sehingga mayoritas masyarakat menggantungkan hidup dari bidang pertanian atau perkebunan. Salah satu daerah yang banyak menghasilkan tanaman buah yaitu di Kabupaten Banyuwangi yang merupakan salah satu kota yang ada di ujung timur daerah Jawa Timur.

Adapun lokasi dalam penelitian ini yaitu di Desa Temurejo Kecamatan Bangorejo Kabupaten Banyuwangi. Peneliti memilih desa tersebut sebagai lokasi penelitian dikarenakan pada desa tersebut terdapat hasil tanaman buah naga yang paling tinggi dibandingkan daerah lain (Hasil observasi). Hal ini dikarenakan buah naga memiliki manfaat yang sangat tinggi, selain itu buah naga juga lebih cepat proses panennya.

Berdasarkan observasi awal yang dilakukan, dapat diketahui bahwa buah naga yang dikembangkan oleh masyarakat Desa Temurejo Kecamatan Bangorejo Kabupaten Banyuwangi merupakan komuditas unggulan. Awalnya petani buah naga hanya sedikit sekitar $10-15$ orang saat ini hampir setiap rumah menanam buah naga. Karena harga buah naga yang relative tinggi dan permintaan pasar yang meningkat menyebabkan banyak petani di Banyuwangi yang 
memutuskan untuk menanam buah naga, padahal sebelumnya mereka menanam buah-buahan lain, seperti semangka dan melon.

Beberapa hal yang harus diperhatikan dalam usahatani buah naga yaitu biaya produksi yang digunakan dalam usahatani buah naga. Dimana biaya produksi usahatani tersebut meliputi sarana produksi yang habis terpakai (seperti bibit, pupuk, pestisida, bahan bakar, bunga modal dalam penanaman lain), lahan (seperti sewa lahan baik berupa uang atau natura, pajak, iuran pengairan), biaya dari alat-alat produksi tahan lama (yaitu seperti bangunan, alat dan perkakas yang berupa penyusutan), tenaga kerja (dari petani itu sendiri dan anggota keluarganya, tenaga kerja tetap atau tenaga bergaji tetap), dan biaya-biaya lain (Prawirokusuma, 2004:47).

Adanya usahatani buah naga yang dilakukan oleh petani di Desa Temurejo Kecamatan Bangorejo Kabupaten Banyuwangi diharapkan dapat memberikan keuntungan kepada petani buah naga tersebut. Banyak dari para petani yang beralih pada usahatani buah naga dikarenakan untuk memperoleh pendapatan yang lebih baik. Para petani mengalami suatu keuntungan jika pendapatan yang diterima oleh petani lebih besar daripada biaya produksi yang dikeluarkan oleh petani tersebut dalam usahatani buah naga.

\section{METODE PENELITIAN}

Berdasarkan permasalahan dan tujuan penelitian yang telah dikemukakan di awal, maka pendekatan yang digunakan dalam penelitian ini adalah penelitian kuantitatif yang menggunakan analisis statistik. Penelitian kuantitatif yang menggunakan analisis statistik ini bertujuan untuk mengetahui pengaruh biaya usahatani buah naga terhadap keuntungan para petani buah naga di Desa Temurejo Kecamatan Bangorejo Kabupaten Banyuwangi. Lokasi penelitian ditetapkan secara purposive area. Penelitian ini dilakukan di Desa Temurejo Kecamtan Bangorejo Kabupaten Banyuwangi.

Populasi dalam penelitian ini adalah seluruh para petani buah naga di Desa Temurejo Bangorejo Banyuwangi yaitu sebanyak 50 petani. Kriteria petani yang dijadikan responden oleh peneliti adalah petani yang minimal mempunyai luas tanaman buah naga sebanyak satu hektar. Adanya jumlah populasi yang kurang dari 100 responden maka peneliti mengambil seluruhnya sebagai responden. Jadi, penelitian ini termasuk dalam penelitian sensus (Arikunto, 2011:115). Dalam penelitian ini

Metode pengumpulan data dalampenelitianini menggunakan metode angket (kuesioner), observasi, wawancara, dan dokumen. Analisis data yang digunakan dalam penelitian ini terdiri dari: analisis garis regresi sederhana, varian garis regresi, uji F, efektivitas garis regresi, dan Standart Of EstimateRegresi Linier Sederhana.

\section{HASIL DAN PEMBAHASAN}

\section{Hasil Penelitian}

Deskripsi Variabel Penelitian

Dari data distribusi frekuensi responden dapat dilihat seberapa besar nilai suatu variabel jika dibandingkan nilai variabel lain, serta bagaimana pola hubungan antar variabel yang ada dalam penelitian.

\section{Deskripsi Variabel Biaya (X)}


Penilaian responden terhadap variabel Biaya (X) menurut klarifikasi tingkatan skor dari masing-masing pernyataan Biaya dijelaskan pada tabel berikut ini:

Tabel 4.1 Distribusi Frekuensi Jawaban Responden Variabel Biaya

\begin{tabular}{|c|c|c|c|}
\hline No. & Biaya & Jumlah & Persentase (\%) \\
\hline 1. & Rp.10.000.000 - Rp.18.000.000 & 26 & 52 \\
\hline 2. & Rp.19.000.000 - Rp. 27.000 .000 & 2 & 4 \\
\hline 3 & Rp.28.000.000 - Rp.36.000.000 & 2 & 4 \\
\hline 4 & Rp.37.000.000 - Rp.45.000.000 & 20 & 40 \\
\hline & Jumlah & 50 & $100 \%$ \\
\hline
\end{tabular}

Sumber: Data Primer diolah (2017) Deskripsi Variabel Keuntungan (Y)

Penilaian responden terhadap variabel Keuntungan (Y) menurut klarifikasi tingkatan skor dari masing-masing pernyataan Keuntungan dijelaskan pada tabel berikut ini:

Tabel 4.2 Distribusi Frekuensi Jawaban Responden Variabel Keuntungan

\begin{tabular}{|c|c|c|c|}
\hline No. & Biaya & Jumlah & Persentase (\%) \\
\hline 1. & Rp.40.000.000-Rp.50.000.000 & 25 & 50 \\
\hline 2. & Rp.51.000.000 - Rp.60.000.000 & 14 & 28 \\
\hline 3 & Rp.61.000.000 - Rp.70.000.000 & 11 & 22 \\
\hline & Jumlah & 50 & $100 \%$ \\
\hline
\end{tabular}

Sumber: Data Primer diolah (2017)

Uji Instrumen Penelitian

Uji Validitas Penelitian

Hasil uji validitas terhadap data dalam penelitian ini adalah sebagai berikut:

Tabel 4.6 Hasil Uji Validitas Biaya Usahatani Buah Naga

\begin{tabular}{|c|c|c|c|c|}
\hline No. & $\begin{array}{c}\text { Item } \\
\text { Pertanyaan }\end{array}$ & $\begin{array}{c}\text { Pearson } \\
\text { Correlation }\end{array}$ & Sig. & Kesimpulan \\
\hline 1. & $\mathrm{X}_{1.1}$ & 0,902 & 0,000 & Valid \\
\hline 2. & $\mathrm{X}_{1.2}$ & 0,900 & 0,000 & Valid \\
\hline 3. & $\mathrm{X}_{1.3}$ & 0,958 & 0,000 & Valid \\
\hline 4. & $\mathrm{X}_{1.4}$ & 0,789 & 0,000 & Valid \\
\hline
\end{tabular}

Sumber: Data Primer diolah (2017)

Berdasarkan Tabel tersebut, dapat diketahui bahwa semua pengujian terhadap variabel $\mathrm{X}$ yaitu biaya usahatani buah naga menunjukkan bahwa seluruh data yang diperoleh adalah valid. Hal tersebut memenuhi persyaratan nilai signifikansi $<0,05$, dengan demikian semua butir pertanyaan dalam angket tersebut dapat digunakan dan dapat dipercaya sebagai data penelitian ini. 
Uji Reliabilitas

Hasil uji reliabilitas terhadap data penelitian disajikan sebagai berikut:

Tabel 4.7 Hasil Uji Reliabilitas

\begin{tabular}{|c|c|c|c|}
\hline No. & Variabel & Cronbach alpha & Keterangan \\
\hline 1. & $\mathrm{X}$ & 0,906 & Reliabel \\
\hline
\end{tabular}

Sumber: Data Primer Diolah (2017)

Berdasarkan uji reliabilitas di atas, suatu instrumen atau angket dari variabel biaya usahatani buah naga (X) terbukti reliabel, dikarenakan nilai biaya usahatani buah naga (X) sebesar 0,906 lebih besar dari angka kritis yaitu sebesar 0,33. Dimana untuk angka kritis 0,33 diperoleh dari jumlah instrument angket yaitu sebanyak 5 yang termasuk dalam kategori angka 0,33 . Hal ini membuktikan hasil penelitian cukup dapat dipercaya dan sesuai dengan kenyataannya, dan hasilnya tetap sama meskipun angket disebarkan sebanyak dua kali kepada responden.

Analisis Data

Analisis Inferensial

Analisis Inferensial merupakan analisis statistik dengan menggunakan rumus statistik yang digunakan untuk menguji hipotesis yang diajukan oleh peneliti dalam melakukan penelitian. Adapun langkah-langkah dalam analisis ini adalah sebagai berikut:

A. Analisis Garis Regresi Sederhana

Hasil analisis garis regresi sederhana disajikan pada tabel berikut ini:

Tabel 4.9 Hasil Analisis Garis Regresi Sederhana

\begin{tabular}{|c|l|l|}
\hline Variabel Penelitian & \multicolumn{1}{|c|}{ Label } & Koefisien Regresi \\
\hline $\mathrm{A}$ & Konstanta & 0,449 \\
\hline $\mathrm{X}$ & Biaya Usahatani Buah Naga & 0,206 \\
\hline $\begin{array}{l}\text { Rsquare }=0,786 \\
\text { Multiple R }=0,887 \\
\text { F rasio }=331,380\end{array}$ \\
\hline
\end{tabular}

Sumber: Data Primer diolah (2017)

Berdasarkan tabel tersebut, maka persamaan garis regresi sederhana yang diperoleh dalam penelitian ini adalah sebagai berikut:

$$
\hat{\mathrm{Y}}=0,449+0,206 \mathrm{X}+\mathrm{e}
$$

Sesuai dengan persamaan regresi yang diperoleh, maka model regresi tersebut dapat diinterpretasikan sebagai berikut:

1. Nilai konstanta $=0,449$. Nilai konstanta menunjukkan nilai positif sebesar 0,449 . Hal ini menunjukkan apabila biaya usahatani buah naga dan ei nilainya konstan (nol), maka keuntungan para petani buah naga di Desa Temurejo Kecamatan Bangorejo Kabupaten Banyuwangi (Y) sebesar 0,449. Hal ini membuktikan bahwa jika hasil usahatani buah naga yang dilakukan tidak sesuai dengan harapan, maka keuntungan para petani tetap sebesar 0,449 .

2. Nilai koefisien $\mathrm{b}=0,206$, berarti bahwa apabila nilai biaya usahatani buah naga(X) mengalami kenaikan sebesar satu poin, sementara variabel independen lainnya bersifat tetap, maka keuntungan para petani buah naga di Desa Temurejo Kecamatan Bangorejo Kabupaten Banyuwangi (Y) akan mengalami peningkatan sebesar 0,206 point. 
B. Analisis Varian Garis Regresi

Adapun besarnya varian garis regresi antara variabel bebas $(\mathrm{X})$ dan variabel terikat $(\mathrm{Y})$ dapat dilihat pada tabel berikut:

Tabel 4.10 Rekapitulasi Biaya Usahatani Buah Naga Terhadap Keuntungan Para Petani Buah Naga di Desa Temurejo Kecamatan Bangorejo Kabupaten Banyuwangi

\begin{tabular}{|l|c|}
\hline \multicolumn{1}{|c|}{ Variabel } & R (Multiple R) \\
\hline $\begin{array}{l}\text { Pengaruh Biaya usahatani buah naga(X) terhadap } \\
\text { Keuntungan Petani (Y) }\end{array}$ & 0,887 \\
\hline
\end{tabular}

Sumber: Data Primer Diolah (2017)

Berdasarkan perhitungan di atas dapat diketahui bahwa nilai koefisisen korelasi sebesar 0,887 berarti bahwa biaya usahatani buah naga $(\mathrm{X})$ memiliki pengaruh yang nyata/signifikan dengan keuntungan para petani buah naga di Desa Temurejo Kecamatan Bangorejo Kabupaten Banyuwangi (Y). Tingkat hubungan tersebut dapat dikategorikan sebagai pengaruh yang sangat kuat.

\section{Uji F}

Berdasarkan perhitungan hasil SPSS 22.0 for windows, diketahui nilai $\mathrm{F}_{\text {hitung }}$ sebagai berikut:

Tabel 4.12 Rekapitulasi Hasil SPSS Untuk Uji F

\begin{tabular}{|l|l|l|l|l|}
\hline Variabel & $F_{\text {hitung }}$ & $F_{\text {tabel }}$ & A & Sig. F \\
\hline X terhadap Y & 331,380 & 4,043 & 0,05 &, 000 \\
\hline
\end{tabular}

Sumber: Data Primer (2017), diolah

Berdasarkan tabel di atas, diketahui bahwa besarnya $\mathrm{F}_{\text {hitung }}=331,380>\mathrm{F}_{\text {tabel }}=4,043$ dengan tingkat signifikansi $\mathrm{F}=0,000<a=0,05$. Hal ini menunjukkan bahwa variabel biaya usahatani buah naga memiliki pengaruh yang signifikan terhadap keuntungan para petani buah naga di Desa Temurejo Kecamatan Bangorejo Kabupaten Banyuwangi. Berdasarkan data tersebut dapat disimpulkan bahwa Ho ditolak dan Ha diterima yaitu 'ada pengaruh yang signifikan variabel biaya usahatani buah naga terhadap keuntungan para petani buah naga di Desa Temurejo Kecamatan Bangorejo Kabupaten Banyuwangi’.

D. Koefisien Determinasi $\left(\mathrm{R}^{2}\right)$

Koefisien determinasi digunakan untuk mengukur besarnya proporsi sumbangan variabel bebas (X) secara simultan atau bersama-sama terhadap variabel terikat (Y). Hasil SPSS 22.0 for windows diperoleh nilai koefisien determinasi $\left(\mathrm{R}_{\text {square }}\right)$ sebesar 0,786 .

$\mathrm{R}_{\text {square }} \times 100 \%=0,786 \times 100 \%=78,6 \%$ artinya korelasi tinggi. (Sugiyono, 2011: 184). Hal ini menunjukkan bahwa besarnya persentase biaya usahatani buah naga terhadap keuntungan para petani buah naga di Desa Temurejo Kecamatan Bangorejo Kabupaten Banyuwangi sebesar $78,6 \%$. sedangkan sisanya yaitu $21,4 \%$ dipengaruhi variabel bebas lainnya yang tidak diteliti dalam penelitian ini yaitu penggunaan teknologi, kualitas produksi, dan kepuasan produksi.

\section{E. Standart Error of Estimate}

Hasil pengolahan data bagian model Summary menunjukkan bahwa nilai StandartError Of Estimate dalam analisis garis refresi sederhana sebesar 0,69523. Hal tersebut menunjukkan 
bahwa variasi nilai Y actual dari garis regresinya adalah sebesar 0,69523. Besarnya Standart Error of Estimate sebesar 0,69523 menunjukkan besarnya penyimpangan variabel keuntungan petanbi buah naga terhadap garis regresinya.

Hal ini berarti bahwa keuntungan petani buah naga tidak hanya dipengaruhi biaya usahatani buah naga saja, namun juga dipengaruhi oleh variabel lain yang tidak diteliti dalam penelitian ini.

\section{Pembahasan}

Berdasarkan penelitian dan analisis data yang telah dilakukan dapat diketahui bahwa ada pengaruh yang signifikan variabel biaya usahatani buah naga terhadap keuntungan para petani buah naga di Desa Temurejo Kecamatan Bangorejo Kabupaten Banyuwangi yaitu sebesar 78,6\% yang termasuk kategori tinggi. Adapun biaya produksi tersebut meliputi, sarana produksi yang habis terpakai (seperti bibit, pupuk, pestisida dan lain-lain), lahan (seperti sewa lahan baik berupa uang atau natura, pajak, iuran pengairan), biaya dari alat-alat produksi tahan lama (seperti bangunan, alat dan perkakas yang berupa penyusutan), dan tenaga kerja dari petani itu sendiri.

Sarana produksi yang habis terpakai (seperti bibit, pupuk, pestisida dan lain-lain) merupakan hal yang harus diperhatikan oleh para petani. Hal ini dikarenakan, sarana produksi yang habis terpakai (seperti bibit, pupuk, pestisida dan lain-lain) merupakan penentu kualitas dari hasil produksi buah naga. Dalam hal ini bibit buah naga yang dipilih yaitu bibit yang berasal dari indukan yang memiliki kualitas bagus yaitu indukan yang sudah tua dan berwarna hijau tua keabuan, sudah pernah berbuah, dan memiliki buah yang besar, telah berakar dan bertunas, dan sudah berumur sekitar $2-3$ bulan. Otomatis bibit yang memiliki kriteria tersebut juga mempengaruhi harga dari bibit tersebut yaitu lebih mahal dari pada bibit yang biasanya.

Untuk faktor produksi dalam usahatani buah naga yang ketiga yaitu mengenai biaya dari alat-alat produksi tahan lama (seperti bangunan, alat dan perkakas yang berupa penyusutan). Biaya dari alat-alat produksi tahan lama (seperti bangunan, alat dan perkakas yang berupa penyusutan) merupakan hal yang cukup penting dalam upaya usahatani buah naga. Hal ini dikarenakan alat-alat produksi tahan lama (seperti bangunan, alat dan perkakas yang berupa penyusutan) sangat mempengaruhi kelancaran usahatani buah naga yang dilakukan oleh petani. Dimana alat-alat produksi tahan lama sangat mempengaruhi jumlah kuantitas dan kualitas buah naga yang dihasilkan. Seperti petani buah naga yang menggunakan lampu, maka akan menghabiskan lebih banyak biaya daripada petani yang tidak menggunakan lampu.

Untuk faktor produksi usahatani yang terakhir yaitu tenaga kerja. Tenaga kerja merupakan hal yang harus diperhatikan oleh para petani dalam melakukan usahatani buah naga. Hal ini dikarenakan dalam melakan perawatan buah naga, petani membutuhkan tenaga kerja. Oleh karena itulah petani harus memperhitungkan biaya untuk tenaga kerja tersebut.

Para petani harus dapat memperhitungkan segala biaya produksi dalam melakukan usahatani buah naga agar tidak mengalami kerugian, sehingga para petani harus dapat memperhitungkan biaya produksi usahatani yang dibutuhkan dengan jumlah pendapatan yang diperoleh. Dalam hal ini petani harus dapat menekan biaya produksi untuk memperoleh keuntungan yang sebesar-besarnya. Mubyarto (2002:45) menjelaskan bahwa petani akan memperhitungkan dan membandingkan antara penerimaan dan biaya, di mana semakin tinggi rasio perbandingan ini maka usaha yang dilaksanakan semakin menguntungkan. 
Adanya usahatani buah naga yang dilakukan oleh para petani buah naga di Desa Temurejo Kecamatan Bangorejo Kabupaten Banyuwangi harus memperhatikan segala biaya produksi dalam melakukan usahatani buah naga tersebut. Hal ini dikarenakan untuk memperoleh keuntungan yang maksimal, seorang petani harus dapat memperhitungkan biaya produksi dalam melakukan usahatani yang akan dibandingkan dengan penerimaan yang akan dipeorleh. Menurut Mubyarto (2002:45) menjelaskan bahwa petani akan memperhitungkan dan membandingkan antara penerimaan dan biaya, di mana semakin tinggi rasio perbandingan ini maka usaha yang dilaksanakan semakin menguntungkan.

Menurut Gustiyana (2004:60), pendapatan bersih, yaitu seluruh pendapatan yang diperoleh petani dalam satu tahun dikurangi dengan biaya produksi selama proses produksi. Biaya produksi meliputi biaya riil tenaga kerja dan biaya riil sarana produksi. Jadi, pendapatan bersih/keuntungan dari usahatani adalah total penerimaan yang berasal dari nilai penjualan hasil ditambah dari hasil-hasil yang dipergunakan sendiri, dikurangi dengan total nilai pengeluaran yang terdiri dari :pengeluaran untuk input (benih, pupuk, pestisida, obat-obatan), pengeluaran untuk upah tenaga kerja dari luar keluarga, pengeluaran pajak dan lain-lain. Oleh karena itulah biaya produksi usahatani sangat berpengaruh terhadap keuntungan para petani buah naga di Desa Temurejo Kecamatan Bangorejo Kabupaten Banyuwangi.

Berdasarkan pemaparan diatas dapat disimpulkan bahwa biaya usahatani buah naga merupakan salah satu faktor yang mempengaruhi keuntungan para petani. Hal ini dikarenakan dengan melakukan usahatani buah naga, maka pendapatan yang diterima oleh para petani mengalami peningkatan, hal ini menandakan bahwa petani memperoleh keuntungan. Berdasarkan hasil penelitian dan pembahasan dalam penelitian ini membuktikan bahwa hipotesis dalam penelitian ini diterima yaitu ada pengaruh yang signifikan variabel biaya usahatani buah naga terhadap keuntungan para petani buah naga di Desa Temurejo Kecamatan Bangorejo Kabupaten Banyuwangi diterima.

\section{KESIMPULAN DAN SARAN \\ Kesimpulan}

Berdasarkan analisis data dan hasil pembahasan penelitian yang telah diuraikan pada bab sebelumnya, maka dapat disimpulkan bahwa ada pengaruh yang signifikan variabel biaya usahatani buah naga terhadap keuntungan para petani buah naga di Desa Temurejo Kecamatan Bangorejo Kabupaten Banyuwangi yaitu sebesar 78,6\%, sedangkan sisanya yaitu 21,4\% dipengaruhi variabel bebas lainnya yang tidak diteliti dalam penelitian ini yaitu penggunaan teknologi, kualitas produksi, dan kepuasan produksi.

\section{Saran}

Berdasarkan kesimpulan di atas dari penelitian ini, maka peneliti ingin memberikan saran sebagai berikut:

1. Bagi petani, untuk lebih memperhatikan kualitas bibit buah naga dan pupuk yang digunakan agar dapat menghasilkan buah naga dengan kualitas yang terbaik, sehingga dapat meningkatkan keuntungan yang diperoleh.

2. Bagi peneliti lain, diharapkan bagi peneliti lain yang akan melakukan penelitian serupa dengan penelitian ini untuk mengambil variabel lain yang tidak turut diteliti dalam penelitian 
ini, supaya dapat menciptakan penelitian-penelitian yang lebih baik dan nantinya sebagai tambahan referensi penelitian yang sejenis

\section{DAFTAR BACAAN}

Arikunto, S. 2011. Prosedur Penelitian, Suatu Pendekatan Praktek. Jakarta: Rineka Cipta Prawirokusuma, S, 2001. Ilmu Usahatani. Edisi pertama. Yogyakarta: BPFE

Sugiyono. 2010. Statistic Untuk Penelitian. Bandung: Alfabeta

Prayitno, H. dan Arsyad, L. 2007. Petani Desa dan Kemiskinan. Yogyakarta: BPFE

Sukirno. 2008. Makro Ekonomi Teori Pengantar. Jakarta: Raja Grafindo Perkasa.

Suratiyah. 2006. Ilmu Usahatani. Jakarta: Penebar Swadaya 